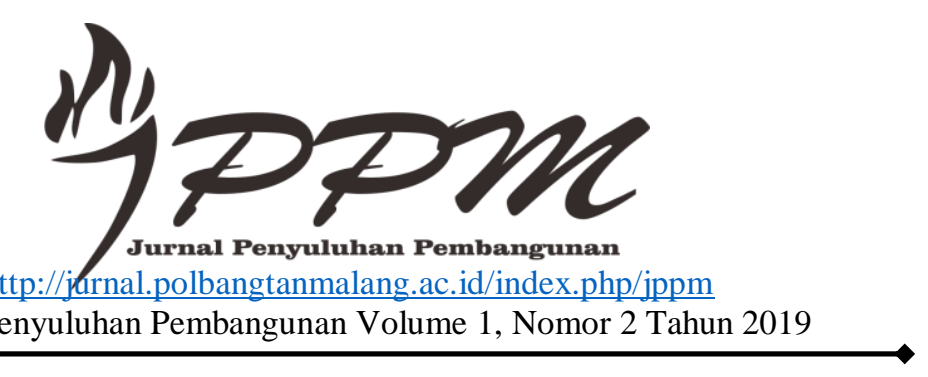

\title{
PENGETAHUAN DAN SIKAP PETERNAK TENTANG TEKNOLOGI PENGOLAHAN JERAMI PADI
}

\section{STUDY OF FARMERS' KNOWLEDGE AND ATTITUDES ABOUT THE TECHNOLOGY OF PROCESSING RICE STRAW}

\author{
Kartika budi utami ${ }^{1}$, Ratna fitri hidayah ${ }^{2}$, Isyunani ${ }^{3}$ \\ 1,2,3 Program Studi Penyuluhan Peternakan dan Kesejahteraan Hewan, Polbangtan Malang, \\ 65200 Malang \\ e-mail: kartika.b.utami@polbangtanmalang.ac.id, ratnafitri103@gmail.com, \\ isyunani@ polbangtanmalang.ac.id
}

\begin{abstract}
Abstrak
Tujuan penelitian yaitu mendeskripsikan pengetahuan dan sikap peternak Margo Utomo 3 tentang teknologi pembuatan pakan lengkap jerami padi. Metode penelitian yang digunakan yaitu studi kasus dan survei. Materi penelitian yaitu 30 orang peternak sapi potong yang ditentukan secara purposive sampling. Kajian telah dilakukan pada Mei 2018. Data primer berupa pengetahuan dan sikap peternak diperoleh dengan menggunakan kuesioner. Data dianalisa secara deskriptif. Hasil kajian pengetahuan menunjukkan bahwa sebanyak 36,7\% responden termasuk kategori pengetahuan rendah, pengetahuan kategori sedang sebanyak 40\%, dan pengetahuan kategori tinggi sebanyak 23,3\%. Hasil analisa sikap menunjukkan bahwa sebanyak 18 orang atau $60 \%$ responden memiliki sikap menerima dan sebanyak 12 orang atau $40 \%$ responden memiliki sikap menolak. Kesimpulan dari penelitian ini yaitu peternak memiliki kategori pengetahuan sedang dan menerima teknologi pakan lengkap jerami padi.
\end{abstract}

Kata Kunci-Jerami padi, Sapi potong, Pakan lengkap, Pengetahuan, Sikap.

\begin{abstract}
The aim of the study is to describe the knowledge and attitudes of Margo Utomo 3 farmers about the technology of making complete feed for rice straw. The study method used is a survey. The study material is 30 farmers who are determined by purposive sampling. The study was conducted in November 2017 - May 2018. Primary data in the form of knowledge and attitudes of farmers are obtained by using a questionnaire. Data is analyzed descriptively. The results of the study of knowledge show that as many as $36.7 \%$ of respondents included the category of low knowledge, medium category knowledge as much as 40\%, and high category knowledge as much as $23.3 \%$. The results of the attitude study showed that as many as 18 people or $60 \%$ of respondents had the attitude of accepting and as many as 12 people or $40 \%$ of respondents had the attitude of refusing. The conclusion of this study is that farmers have good knowledge and receive complete feed technology for rice straw.
\end{abstract}

Keywords-Rice straw, Beef cattle, Complete feed, Knowledge, Attitude

\section{PENDAHULUAN}

Sistem peternakan meliputi breeding (bibit/bakalan), feeding (pakan) dan management (manajemen). Pakan merupakan biaya produksi yang terbesar dalam usaha 
peternakan, selain itu ketersediaan bahan pakan di Indonesia terutama untuk ternak ruminansia yang berupa hijauan sangat fluktuatif dan bergantung pada musim. Bahan pakan yang berasal dari limbah hasil pertanian seperti jerami padi dimanfaatkan oleh peternak sebagai alternatif pakan terutama saat musim kemarau. Yanuartono, dkk (2017) mengungkapkan bahwa hasil-hasil penelitian dari berbagai negara dan wilayah di Indonesia menunjukkan bahwa kadar protein kasar pada jerami menunjukkan kisaran angka $3-5 \%$, sehingga perlu dilakukan pengolahan melalui berbagai metode untuk meningkatkan kualitas jerami melalui peningkatan kadar protein kasar tersebut. Salah satu upaya untuk mengoptimalkan pemanfaatan jerami padi sebagai pakan ternak sapi potong adalah melalui teknologi pakan lengkap. Teknologi pakan lengkap merupakan metode atau teknik pembuatan pakan dimana hijauan dan konsentrat dicampur menjadi homogen melalui proses perlakuan fisik dan suplementasi yang dikemas dalam bentuk tertentu agar pemberian kepada ternak efektif dan memudahkan dalam penyimpanan.

Desa Toyomarto terletak di bawah kaki gunung Arjuna, dengan luas lahan sawah 95 ha dapat menghasilkan 1.033,6 ton/tahun jerami segar dan populasi ternak sapi potong 1.106 ekor, sehingga cukup prospektif untuk wilayah pengembangan sapi potong. Kelompok peternak sapi potong yaitu Margo Utomo 3 memiliki jumlah anggota sebanyak 116 orang. Bertani adalah pekerjaan utama sedangkan beternak sapi merupakan usaha sampingan. Peternak menggunakan hijauan berupa rumput gajah pada musim penghujan dan jerami padi pada musim kemarau tanpa adanya pakan tambahan, sehingga kebutuhan nutrisi sapi potong kurang tepenuhi. Teknologi pakan lengkap diharapkan dapat mengatasi permasalahan peternak di kelompok Margo Utomo 3 dalam menyediakan pakan yang berkualitas bagi sapi potong. Kajian ini dilakukan untuk mendeskripsikan pengetahuan dan sikap peternak tentang teknologi pakan lengkap untuk sapi potong.

\subsection{Lokasi Dan Waktu Kajian}

\section{METODE PENELITIAN}

Kajian telah dilaksanakan di Kelompok Tani Margo Utomo 3 Desa Toyomerto Kecamatan Singosari Kabupaten Malang pada bulan November 2017 - Mei 2018.

\subsection{Materi Kajian}

Materi dalam kajian ini yaitu peternak anggota kelompok Margo Utomo 3. Sampel ditentukan secara sengaja (purposive sampling) dengan kriteria yang telah ditetapkan yaitu: (1) Anggota yang aktif dalam kegiatan kelompok ternak; (2) Memiliki ternak sapi potong 2-5 ekor; (3) Lama usaha ternak sapi potong minimal 3 tahun (4) Peternak yang memiliki lahan sawah minimal 0,25 ha dengan komoditas padi. Jumlah sampel yang memiliki kriteria tersebut berjumlah 30 orang. Kajian ini menggunakan metode survei. Data primer berupa pengetahuan dan sikap peternak diperoleh dengan menggunakan kuesioner melalui wawancara dan observasi. Data sekunder berupa data potensi wilayah diperoleh dari balai penyuluhan pertanian dan instansi terkait.

\subsection{Mengukur Pengetahuan Peternak}

Kuisioner pengetahuan disusun menggunakan skala Guttman, data pengetahuan responden yang diperoleh ditabulasi dan diklasifikasikan secara deskriptif menjadi tiga kategori yaitu;

1. pengetahuan rendah (nilai 25-49)

2. pengetahuan sedang (nilai 50-74)

3. pengetahuan tinggi (nilai $75-100$ )

\subsection{Mengukur Sikap Peternak}

Kuesioner sikap menggunakan skala Likert, data sikap yang diperoleh diukur menggunakan skor $\mathrm{T}$ dengan rumus sebagai berikut: 
Kartika Budi Utami, dkk., Pengetahuan Dan Sikap Peternak Tentang Teknologi Pengolahan.....

$$
T=50+10\left|\frac{X-\bar{X}}{S}\right|
$$

Kesimpulan:

jika skor $\mathrm{T} \geq 50$, maka sikap respoden menerima

jika skor $\mathrm{T}<50$, maka sikap responden menolak.

\subsection{Analisa Data}

Data yang diperoleh selanjutnya dianalisa secara deskriptif.

\section{HASIL DAN PEMBAHASAN}

\subsection{Pengetahuan Peternak Tentang Teknologi Pakan Lengkap Jerami Padi}

Hasil kajian pengetahuan peternak tentang teknologi pakan lengkap jerami padi disajikan pada Gambar 1.

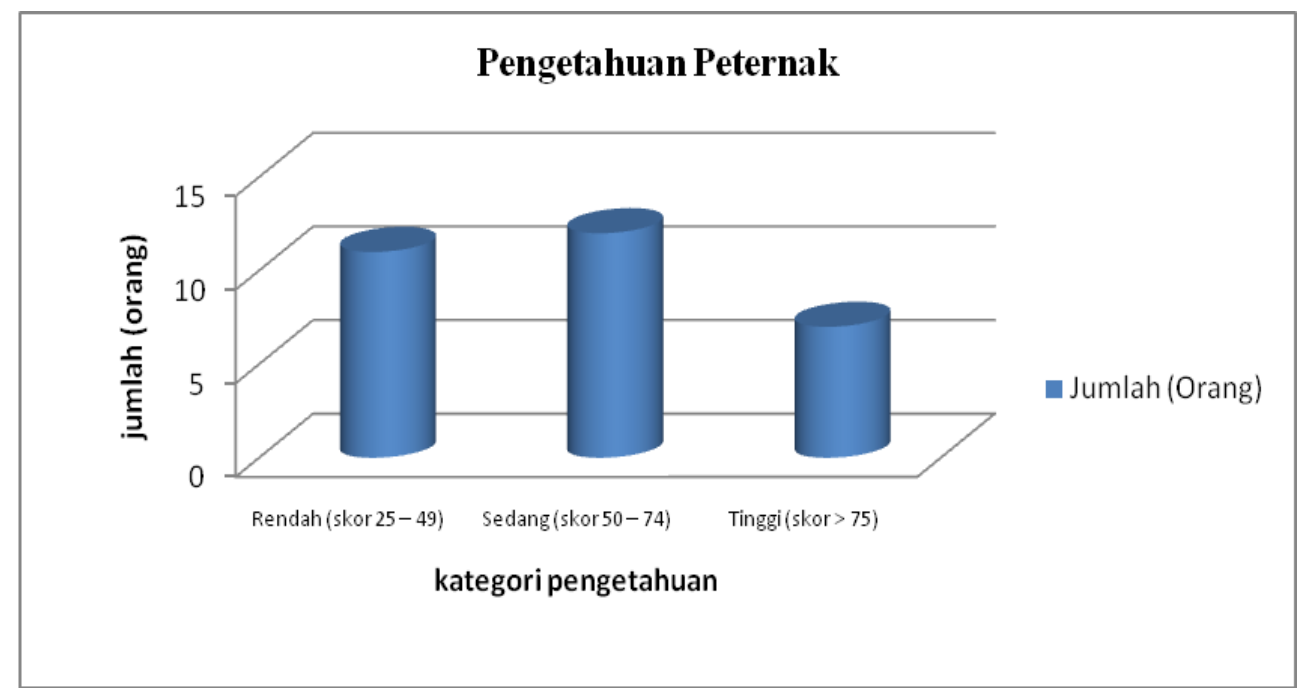

Gambar 1. Pengetahuan Peternak

Gambar 1 menunjukan bahwa secara umum responden pada kategori pengetahuan sedang yaitu 12 orang atau $40 \%$. Peternak diketahui pernah mendapatkan informasi tentang pengolahan jerami padi dari kegiatan penyuluhan yang telah dilakukan oleh instansi pemerintah bidang peternakan yang berdekatan dengan lokasi peternak. Manshur, Dalika dan Islami (2012) melaporkan bahwa kegiatan penyuluhan dan pendampingan yang dilakukan oleh perguruan tinggi dapat meningkatkan pengetahuan bagi peternak sapi perah di Desa Cidatar dan Desa Sukawargi Kecamatan Cisurupan dalam menerapkan teknologi pakan tepat seperti pertanian terintegrasi, pengolahan jerami, dan pembuatan pakan silase. Said, dkk (2018) juga mengungkapkan bahwa peningkatan kapasitas pengetahuan bagi para peternak penting untuk memudahkan para peternak menerima inovasi teknologi. Kegiatan pelatihan yang dilakukan dalam kerangka tersebut merupakan kegiatan kerjasama antara pihak perguruan tinggi, mitra maupun pihak pemerintah daerah di Kecamatan Libureng, Kab. Bone. Program peningkatan kapasitas telah memberikan inovasi baru bagi para anggota kelompok tani di Kecamatan Libureng dalam pengembangan ternak sapi dan pengolahan limbah ternak.

Penyuluhan yang pernah diikuti peternak Margo Utomo 3 menggunakan metode ceramah dan media berupa leaflet, namun tanpa praktik langsung pembuatan pengolahan pakan ternak. Abdullah dan Ibrahim (2014) menyatakan bahwa pemilihan metoda tidaklah selalu sama menurut waktu dan tempat, tetapi tergantung pada permasalahan,

$$
\text { Jurnal Penyuluhan Pembangunan } 1 \text { (2) } 2019 \text { 56-61 | } 58
$$


situasi dan kondisi yang ada. Suatu metoda tertentu akan lebih efektif bila sesuai dengan permasalahan yang ada, tetapi sebaliknya sekalipun menggunakan metoda yang canggih tidak berarti apa-apa bila kurang relevan dengan konteks yang ada. Artinya, melalui metode ceramah pada penyuluhan yang pernah diikuti, peternak telah mendapatkan wawasan dan informasi sehingga pengetahuan tentang pengolahan pakan telah diterima sebelumnya. Hal ini berbeda dengan hasil penelitian yang dilakukan oleh Karnawan, dkk (2017) bahwa pengetahuan peternak Gapoktan Sriasih tentang pengolahan pakan fermentasi termasuk kategori tinggi, karena rata-rata responden sudah mengetahui tahapan-tahapan dalam melakukan fermentasi. Pada penelitian ini, peternak Margo Utomo 3 hanya pernah mendapatkan informasi secara teori tapi mereka belum pernah mempraktikkannya secara langsung.

Penelitian Lestari dkk (2015) juga mengungkapkan bahwa sebagian besar peternak sapi potong di Kecamatan Sinjai yaitu $75 \%$ mempunyai pengetahuan kategori sedang terhadap penyuluhan dan demonstrasi teknologi pengolahan limbah pertanian dalam bentuk silase, UMB dan pakan komplit. Abdullah (2016) melaporkan bahwa lambatnya proses adopsi peternak di Bulukumba disebabkan oleh kurangnya minat pada inovasi teknologi akibat rendahnya pengetahuan dalam penerapan inovasi teknologi pakan. Penyebab lainnya adalah kurang lancarnya komunikasi informasi tentang inovasi teknologi pakan sehingga peternak takut mengambil resiko jika gagal dalam penerapannya.

\subsection{Sikap Peternak Terhadap Teknologi Pakan Lengkap Jerami Padi}

Hasil kajian sikap peternak terhadap teknologi pakan lengkap jerami padi disajikan pada Gambar 2.

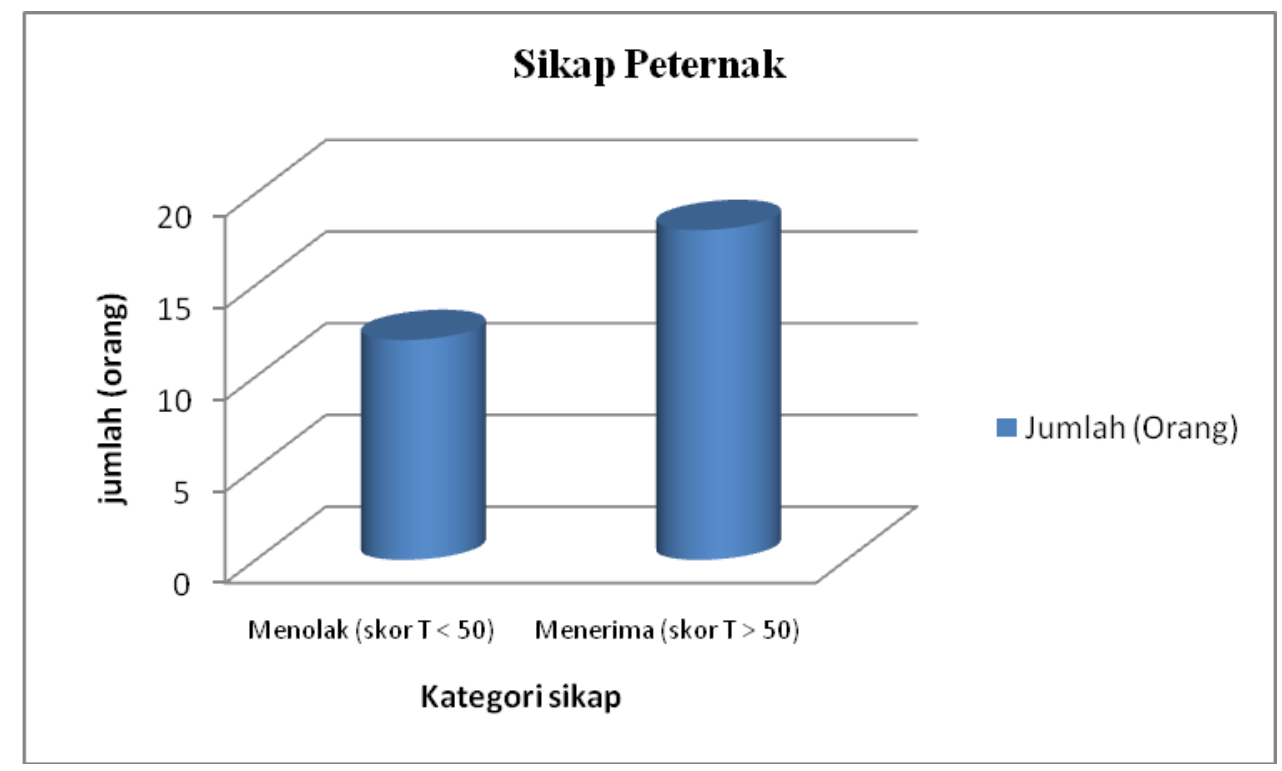

Gambar 2. Sikap Peternak

Secara umum, sebanyak $60 \%$ peternak termasuk dalam kategori sikap menerima. Peternak menerima teknologi ini karena peternak mendapatkan solusi atas permasalahan yang selama ini dihadapi yaitu dalam mencukupi pakan sapi potong terutama pada musim kemarau. Kendala peternak dalam mencukupi rumput diantaranya persaingan lahan untuk rumput, kesibukan peternak sebagai petani dan kegiatan mengurus usaha lainnya menyebabkan peternak memiliki waktu yang terbatas untuk mencari rumput. Selain itu, bahan dan peralatan yang mudah didapat dan tersedia di lokasi kajian serta cara pembuatan pakan lengkap yang sederhana dan dengan waktu fermentasi selama 2 
Kartika Budi Utami, dkk., Pengetahuan Dan Sikap Peternak Tentang Teknologi Pengolahan.....

minggu, juga menjadi alasan peternak menerima teknologi pembuatan pakan lengkap jerami padi.

Suharyon et al. (2014) dalam Gustiani dan Permadi (2015) menyatakan bahwa agar penguasaan teknologi cepat terdifusi dan dapat diterapkan, maka perlu memperkuat faktor pendorong dan meminimalkan faktor penghambat. Meminimalkan faktor penghambat dapat dilakukan dengan memperkuat faktor pendorong seperti melakukan demplot, temu lapang, kunjungan lapang, dan memperluas akses teknologi. Lestari dkk (2015) juga mengungkapkan bahwa sebagian besar atau 83,3\% peternak sapi potong di Kecamatan Sinjai berminat terhadap pakan hasil teknologi limbah pertanian dalam bentuk silase, UMB dan pakan komplit. Lebih lanjut, Lestari, dkk (2015) menjelaskan bahwa hambatan dalam adopsi teknologi pengolahan limbah pertanian sebagai pakan ternak adalah kurang sarana, kurang biaya, kurang tenaga kerja, kurang pengetahuan dan kurang motivasi. Disarankan ada kerjasama antara peternak sapi potong, dinas peternakan setempat, penyuluh dan lembaga keuangan. Disamping perlu dilakukan penyuluhan/pelatihan dan demonstrasi yang lebih intensif, penyediaan fasilitas kredit serta sarana untuk meningkatkan adopsi teknologi pengolahan limbah pertanian sebagai pakan ternak.

Ketersediaan limbah jerami padi yang melimpah di lokasi kajian sangat berpotensi untuk dimanfaatkan oleh peternak Margo Utomo 3 sebagai pakan sapi potong karena akan mengurangi biaya, serta meringankan kerja peternak dalam merumput. Hasil penelitian yang dilakukan oleh Kurnawan, dkk (2017) juga menemukan bahwa sikap petani Gapoktan Sriasih terhadap pengolahan pakan fermentasi termasuk dalam kategori setuju. Artinya anggota Simantri bersikap positif, mau menerima dan melaksanakan pengolahan pakan ternak fermentasi.

\section{KESIMPULAN}

Dari penelitian ini dapat disimpulkan bahwa pengetahuan responden tentang pakan lengkap jerami padi termasuk kategori sedang. Kategori pengetahuan sedang sebanyak $40 \%$ atau 12 orang dan pengetahuan kategori tinggi sebanyak 23,3\% atau 7 orang. Sebanyak $60 \%$ responden atau 18 orang menerima teknologi pakan lengkap jerami padi, sehingga pengembangan teknologi pakan di kelompok tani Margo Utomo 3 dapat terus diupayakan untuk mendukung mengembangkan peternakan sapi potong di Kecamatan Singosari.

\section{V.SARAN}

Agar dilakukan kegiatan penyuluhan dan pendampingan secara intensif kepada peternak terutama tentang aplikasi teknologi pakan lengkap jerami padi.

\section{DAFTAR PUSTAKA}

Abdullah, A dan Ibrahim, H. 2014. Persepsi Peternak terhadap Kinerja Penyuluh dalam Pengembangan Teknologi Pengolahan Jerami Padi dan Limbah Ternak Sapi Potong. JITRO Vol.1 No.1, September 2014.

Abdullah, A. 2016. Proses Adopsi Teknologi Fermentasi Jerami Padi Sebagai Pakan Sapi Potong pada Peternakan Rakyat di Kabupaten Bulukumba, Sulawesi Selatan. Sosiohumaniora, Volume 18 No. 1 Maret 2016: 1 - 9.

Azwar, S. 2013. Sikap Manusia Teori dan Pengukurannya. Pustaka Pelajar. Yogyakarta. 
Kartika Budi Utami, dkk., Pengetahuan Dan Sikap Peternak Tentang Teknologi Pengolahan.....

Gustiani, E dan Permadi, K. 2015. Tingkat Adopsi Peternak terhadap Teknologi Pengolahan Tongkol Jagung Pakan Ternak di Majalengka. Agros Vol. 17 No.1, Januari 201: 88-94. ISSN 1411-0172.

Kurnawan, I, P, J, Sudarta, W, Suardi, I, D, P, O. 2017. Perilaku Petani terhadap Teknologi Pengolahan Pakan Ternak Fermentasi Jerami Padi (Kasus pada Simantri 222 Gapoktan Sriasih di Desa Pohsanten, Kecamatan Mendoyo, Kabupaten Jembrana). E-Jurnal Agribisnis dan Agrowisata. ISSN: 2301-6523. Vol. 6, No. 2, April 2017. http://ojs.unud.ac.id/index.php/JAA.

Lestari, V. S, Rahardja, D. P, Romber, M. B. 2015. Pengetahuan dan Sikap Peternak Sapi Potong terhadap Teknologi Pengolahan Limbah Pertanian Sebagai Pakan Ternak. JITP Vol. 4 No. 2, Juli 2015.

Mansyur, Dhalika, T dan Islami, R.Z. 2012. Implementasi Strategi dan Teknologi Kecukupan Pakan Sepanjang Tahun untuk Pengembangan Peternakan Sapi Perah di Desa Sukawargi dan Cidatar Kecamatan Cisurupan Kabupaten Garut. Dharmakarya: Jurnal Aplikasi Ipteks untuk Masyarakat . Vol. 1, No. 2, November 2012: 64 - 73. ISSN 1410 - 5675.

Said, M. I, Hatta, M dan Rohani, St. 2018. Peningkatan Kapasitas Dalam Teknologi Pakan Dan Pengolahan Limbah Ternak Pada Kelompok Peternak Sapi Potong Di Desa Mattirowalie, Kec. Libureng, Kab. Bone. Jati Emas. Jurnal Aplikasi Teknik dan Pengabdian Masyarakat. Vol. 2 No. 2 Oktober 2018. e-ISSN: 25500821.

Yanuartono, Purnamaningsih, H. Indarjulianto, S, Nururrozi, A. 2017. Potensi Jerami Sebagai Pakan Ternak Ruminansia. Jurnal Ilmu-Ilmu Peternakan 27 (1): 40 62. ISSN : 0852-3681. E-ISSN : 2443-0765. http://jiip.ub.ac.id/ 